\title{
PRESTASI AKADEMIK DAN NON AKADEMIK MAHASISWA PRODI PENDIDIKAN MATEMATIKA ANGKATAN 2012 FAKULTAS TARBIYAH DAN KEGURUAN IAIN ANTASARI BANJARMASIN
}

\author{
Murdan, Rahmawati, Ellen Davita Safaredha
}

\begin{abstract}
Abstrak
Proses akreditasi merupakan bagian penting untuk mengevaluasi keberlangsungan suatu program studi (prodi). Berdasarkan hal tersebut, sangat penting bagi Prodi Pendidikan Matematika untuk memenuhi standar-standar penilaian akreditasi yang telah ditetapkan oleh BAN-PT untuk menjaga keberlangsungannya. Adapun salah satu standar penilaian akreditasi prodi adalah terkait dengan kemahasiswaan dan lulusan, yang mencakup pencapaian prestasi atau reputasi mahasiswa di bidang akademik dan non-akademik. Berdasarkan hal tersebut dilakukan penelitian tentang "Prestasi Akademik dan Non Akademik Mahasiswa Prodi Pendidikan Matematika Angkatan 2012 Fakultas Tarbiyah dan Keguruan lain Antasari Banjarmasin”, dengan tujuan untuk mengetahui bagaimana pencapaian prestasi mahasiswa pada dua bidang tersebut.

Penelitian ini menggunakan metode deskriptif dengan subjek penelitian adalah seluruh mahasiswa angkatan 2012 Prodi Pendidikan Matematika, Fakultas Tarbiyah dan Keguruan, IAIN Antasari Banjarmasin. Objek dalam penelitian ini adalah data prestasi akademik dan non akademik mahasiswa Prodi PMTK angkatan 2012. Teknik pengumpulan data yang digunakan adalah dengan dokumentasi dan wawancara. Teknik analisis data menggunakan statistik deskriptif.

Hasil penelitian menunjukkan bahwa prestasi akademik mahasiswa berada pada kualifikasi amat baik, dengan perolehan SKS di atas standar minimal. Prestasi non akademik mahasiswa berada pada kualifikasi baik, dengan perolehan skor SKK di atas standar minimal.
\end{abstract}

Kata Kunci: prestasi akademik dan prestasi non akademik.

\section{Pendahuluan \\ Berdasarkan Undang-Undang RI Nomor 20 Tahun 2003 tentang sistem pendidikan nasional, Peraturan Pemerintah RI Nomor 19 Tahun}


2005 dan perkembangan kebijakan tentang pendidikan tinggi sangat menekankan pada mutu dan akuntabilitas publik institusi perguruan tinggi sehingga untuk mewujudkan hal tersebut institusi perlu diakreditasi. Akreditasi adalah bentuk penilaian (evaluasi) dan merupakan proses menentukan sejauh mana tujuan pendidikan dapat dicapai.

Manfaat dari adanya evaluasi adalah memberikan informasi yang dapat dipakai sebagai dasar membuat kebijakan dan keputusan, menilai hasil yang dicapai mahasiswa, menilai keterlaksanaan kurikulum, memberikan kepercayaan pada institusi, memonitor dana yang telah diberikan atau dikeluarkan, dan memperbaiki materi dan program pendidikan. Evaluasi diri dan akreditasi merupakan hal yang sangat penting untuk menilai tingkat pencapaian kinerja suatu perguruan tinggi pada umumnya, dan program studi (prodi) pada khususnya.

Berkenaan dengan akreditasi, surat edaran Dirjen Dikti No. 194/E.E3/AK/2014 Tanggal 25 Februari 2014 tentang Izin Penyelenggaraan dan Akreditasi Institusi Perguruan Tinggi dengan UU No. 12 Tahun 2012 tentang Pendidikan Tinggi pada tanggal 10 Agustus 2012, menjelaskan bahwa:

1. Berdasarkan Pasal 97 huruf a UU No. 12 Tahun 2012, izin pendirian Perguruan Tinggi dan izin penyelenggaraan Program Studi yang sudah diterbitkan sebelum tanggal 10 Agustus 2012 dinyatakan tetap berlaku.

2. Berhubung izin pendirian Perguruan Tinggi sebagaimana dimaksud pada ayat 1 di atas tetap berlaku maka berdasarkan pasal 60 ayat 4 UU No. 12 Tahun 2012, Perguruan Tinggi yang telah memperoleh izin pendirian sebelum tanggal 10 Agustus 2012 sebagaimana dimaksud pada angka 1 dan Perguruan Tinggi tersebut belum terakreditasi dinyatakan memenuhi standar minimum akreditasi sampai tanggal 10 Agustus 2014.

3. Dalam rentang waktu antara penerbitan Surat Edaran ini sampai dengan 10 Agustus 2014 sebagaimana pada angka 2, Perguruan Tinggi tersebut wajib mengajukan surat permohonan akreditasi ulang kepada Badan Akreditasi Nasional Perguruan Tinggi (BAN-PT) dengan melampirkan izin pendirian Perguruan Tinggi. 
Prestasi Akademik dan Non Akademik Mahasiswa Prodi Pendidikan Matematika Angkatan 2012 Fakultas Tarbiyah dan Keguruan IAIN Antasari Banjarmasin

4. Setelah tanggal 10 Agustus 2014 sebagaimana dimaksud pada angka 3 terlampaui, tetapi Perguruan Tinggi tidak mengajukan surat permohonan akreditasi ulang kepada BAN-PT, izin pendirian Perguruan Tinggi tersebut dicabut, dan seterusnya.

Berdasarkan hal tersebut, maka sangat penting bagi Prodi Pendidikan Matematika (PMTK) untuk memenuhi standar-standar penilaian akreditasi yang telah ditetapkan oleh BAN-PT untuk menjaga keberlangsungannya. Adapun salah satu standar penilaian akreditasi prodi adalah terkait dengan kemahasiswaan dan lulusan, yang mencakup pencapaian prestasi atau reputasi mahasiswa di bidang akademik dan nonakademik.

Prestasi bidang akademik mahasiswa dapat dilihat dari Indeks Prestasi Kumulatif (IPK). Selain itu, jumlah SKS yang harus sudah ditempuh mahasiswa selama 4 semester minimal 46 SKS, hal ini dasarkan pada Pedoman Akademik IAIN Antasari pasal 22 (Tim Penyusun, 2013) yang menjelaskan bahwa; (1) Hasil studi empat semester menentukan kebolehan untuk meneruskan studi pada semester berikutnya di fakultas masingmasing, (2) mahasiswa boleh melanjutkan studi di fakultas masing-masing setelah mengikuti 4 semester dengan perolehan sekurang-kurangnya 46 SKS.

Adapun prestasi bidang non akademik adalah prestasi yang ditinjau dari keikutsertaan maupun prestasi mahasiswa, baik dalam penelitian, lomba karya ilmiah, olahraga, dan seni. Prestasi non akademik mahasiswa didokumentasikan dalam bentuk Satuan Kredit Kegiatan (SKK). Skor SKK yang diharapkan telah dikumpulkan mahasiswa minimal berjumlah 30 kredit point. Skor tersebut sekaligus merupakan syarat untuk mengikuti Praktik Pengalaman Lapangan (PPL).

Berdasarkan hal yang telah di uraikan di atas, sangat penting bagi Prodi PMTK untuk mengetahui prestasi mahasiswanya. Untuk itu dilakukan penelitian tentang “Prestasi Akademik dan Non Akademik Mahasiswa Prodi Pendidikan Matematika Angkatan 2012 Fakultas Tarbiyah dan Keguruan lain Antasari Banjarmasin”. Tujuan penelitian ini adalah untuk mengetahui: 
(1) prestasi akademik mahasiswa Prodi PMTK angkatan 2012; dan (2) prestasi non akademik mahasiswa Prodi PMTK angkatan 2012.

\section{Metode Penelitian}

1. Jenis Penelitian

Penelitian ini termasuk jenis penelitian lapangan (field research) dan metode yang digunakan dalam penelitian ini adalah metode deskriptif. Nazir (2003) mengatakan bahwa metode deskriptif adalah suatu metode dalam meneliti sekelompok manusia, suatu objek, suatu set kondisi, suatu sistem pemikiran dengan tujuan untuk membuat deskripsi, gambaran atau lukisan secara sistematis, faktual dan akurat mengenai fakta-fakta serta hubungan antar fenomena yang diselidiki. Penelititan ini mendeskripsikan prestasi akademik dan non akademik mahasiswa yang ditinjau dari perolehan IPK, SKS dan skor SKK semenjak semester 1 sampai dengan semester 4.

2. Lokasi dan Waktu Penelitian

Penelitian ini dilaksanakan di Fakultas Tarbiyah dan Keguruan Prodi Pendidikan Matematika (PMTK). Sedangkan waktu pelaksanaannya dilaksanakan pada bulan September sampai dengan Desember 2014.

\section{Subjek dan Objek Penelitian}

Subjek dalam penelitian ini adalah seluruh mahasiswa prodi PMTK angkatan 2012 Tahun Akademik 2013/2014 yang berjumlah 107 orang dengan rincian sebagai berikut:

Tabel 1. Distribusi Mahasiswa Angkatan 2012

\begin{tabular}{|c|c|c|}
\hline No & Kelas & Jumlah \\
\hline 1 & A & 41 \\
\hline 2 & B & 33 \\
\hline 3 & C & 33 \\
\hline & Jumlah & 107 \\
\hline
\end{tabular}


Prestasi Akademik dan Non Akademik Mahasiswa Prodi Pendidikan Matematika Angkatan 2012 Fakultas Tarbiyah dan Keguruan IAIN Antasari Banjarmasin

Sedangkan objek dalam penelitian ini adalah data prestasi akademik dan non akademik mahasiswa prodi PMTK angkatan 2012 Tahun Akademik 2013/2014.

\section{Data dan Sumber Data}

Data dalam penelitian ini terbagi menjadi 2 (dua) jenis sesuai dengan sumber perolehannya, yaitu: (1) Data Primer, berupa data prestasi akademik dan non akademik mahasiswa yaitu transkrip nilai mahasiswa prodi PMTK angkatan 2012 Fakultas Tarbiyah dan Keguruan IAIN Antasari Banjarmasin Tahun Akademik 2013/2014 dari semester 1 sampai 4, dan bukti kegiatan non akademik mahasiswa yang telah direkapitulasi dalam bentuk skor SKK. (2) Data Sekunder, berupa data yang diambil sebagai pelengkap yang dapat memberikan gambaran umum untuk mendukung penelitian, berupa profil prodi PMTK Fakultas Tarbiyah dan Keguruan IAIN Antasari Banjarmasin.

Adapun sumber data dalam penelitian ini yaitu: (1) Responden, yaitu seluruh mahasiswa angkatan 2012 Prodi PMTK tahun akademik 2013/2014. (2) Dokumentasi, bahan-bahan berupa dokumen atau arsip yang berhubungan dengan penelitian.

\section{Instrumen Penelitian dan Teknik Pengumpulan Data}

Penelitian ini menggunakan instrumen pengumpul data sebagai berikut: (1) Dokumentasi merupakan teknik pengumpulan data yang diperoleh melalui lembar rekapitulasi tentang SKS, IPK dan skor SKK. (2) Wawancara digunakan untuk mengumpulkan informasi tambahan yang berkenaan dengan prestasi mahasiswa, dengan membuat daftar pertanyaan.

\section{Teknik Analisis Data}

Data dalam penelitian dianalisis menggunakan statistik deskriptif untuk mendeskripsikan pretasi akademik dan non akademik mahasiswa 
angkatan 2012 prodi PMTK tahun akademik 2013/2104. Data dianalisis menggunakan:

a. Rata-rata

Data yang diperoleh dianalisis dengan menghitung rata-rata (mean) perolehan IPK, SKS dan skor SKK. Rumus yang digunakan untuk mencari mean menurut Sugiyono (2007) adalah:

$$
M e=\frac{\sum x_{i}}{N}
$$

Keterangan:

$$
\begin{aligned}
\text { Me } & =\text { Mean (rata-rata) } \\
\sum & =\text { Sigma (baca jumlah) } \\
x_{i} & =\text { Nilai } x \text { ke-i sampai ke-n } \\
\mathrm{N} & =\text { Jumlah individu }
\end{aligned}
$$

Untuk mengetahui kualifikasi prestasi akademik mahasiswa digunakan kriteria pengelompokan predikat IPK yang diadaptasi dari pasal 23 ayat (1) terkait keberhasilan studi (Tim Penyusun Pedoman Akademik, 2013), yang dirangkum pada tabel berikut:

Tabel 2. Pedoman Kualifikasi IPK

\begin{tabular}{|c|c|}
\hline IPK & Predikat \\
\hline $3,50-4,00$ & Kumlaude \\
\hline $3,00-<3,50$ & Amat Baik \\
\hline $2,50-<3,00$ & Baik \\
\hline $2,00-<2,50$ & Cukup \\
\hline
\end{tabular}

Untuk mengetahui keberlanjutan studi mahasiswa, ditentukan melalui rata-rata perolehan SKS yang telah ditempuh sebanyak minimal 46 sks. Untuk mengetahiui prestasi non akademik mahasiswa, ditentukan melalui rata-rata perolehan skor SKK minimal 30 kredit poin. Adapun 
Prestasi Akademik dan Non Akademik Mahasiswa Prodi Pendidikan Matematika Angkatan 2012 Fakultas Tarbiyah dan Keguruan IAIN Antasari Banjarmasin

berdasarkan pedoman penilaian SKK, predikat nilai akhir SKK dinyatakan dalam tabel sebagai berikut:

Tabel 3. Pedoman Kualifikasi SKK

\begin{tabular}{|c|c|}
\hline Skor SKK & Predikat \\
\hline $86-$ ke atas & Istimewa \\
\hline $76-<86$ & Baik sekali \\
\hline $66-<76$ & Baik \\
\hline $50-<66$ & Cukup \\
\hline
\end{tabular}

b. Persentase

Teknik ini digunakan untuk menyatakan persentase mahasiswa yang memenuhi jumlah SKS minimal yang sudah ditempuh selama 4 semester, yakni sebanyak 46 SKS; Persentase pencapaian IPK mahasiswa; dan persentase mahasiswa yang memperoleh skor SKK dengan jumlah minimal 30 kredit poin. Adapun rumus yang digunakan untuk menghitung persentase data-data yang akan di analisis menggunakan rumus yang diadaptasi dari Sudijono (2005):

$$
P=\frac{f}{N} \times 100 \%
$$

Keterangan:

$\mathrm{P} \quad=$ Angka persentase

$\mathrm{f} \quad \quad=$ Frekuensi yang sedang dicari persentasenya

$\mathrm{N} \quad=$ Number of Class (Jumlah frekuensi/banyaknya individu)

\section{Hasil dan Pembahasan}

Berdasarkan kegiatan pendataan yang dilakukan untuk mengetahui prestasi akademik dan non akademik mahasiswa Prodi PMTK angkatan 2012 Tahun akademik 2013/2014, diperoleh data-data berupa IPK, SKS dan skor SKK. Prestasi akademik mahasiswa dianalisis melalui perolehan IPK dan SKS, sedangkan prestasi non akademik mahasiswa dianalisis melalui perolehan skor SKK. Berikut ini dipaparkan analisis data penelitian ini. 
1. Prestasi Akademik

Berdasarkan data IPK dan SKS yang diperoleh, data prestasi akademik mahasiswa dapat diuraikan sebagai berikut:

Tabel 4. Kualifikasi IPK Mahasiswa

\begin{tabular}{|c|c|c|c|}
\hline Predikat & IPK & F & $(\%)$ \\
\hline Kumlaude & $3,50-4,00$ & 23 & 21,50 \\
\hline Amat Baik & $3,00-<3,50$ & 65 & 60,75 \\
\hline Baik & $2,50-<3,00$ & 18 & 16,82 \\
\hline Cukup & $2,00-<2,50$ & 1 & 0,93 \\
\hline
\end{tabular}

Berdasarkan tabel 4, dari 107 mahasiswa yang didata perolehan IPK nya selama empat semester, diperoleh frekuensi dan persentase mahasiswa pada masing-masing kualifikasi. Sebanyak 23 mahasiswa atau 21,5\% yang termasuk kualifikasi kumlaude. Sebanyak 65 mahasiswa atau 60,75\% yang termasuk kualifikasi amat baik. Pada kualifikasi baik terdapat 18 mahasiswa atau $16,82 \%$, sedangkan yang berada pada kualifikasi cukup yakni hanya ada 1 mahasiswa atau 0,93\%. Frekuensi tertinggi berada pada kualifikasi amat baik, sebesar 60,75\%. Adapun nilai rata-rata IPK mahasiswa adalah 3,24 dan nilai ini termasuk dalam kualifikasi amat baik.

Berdasarkan kriteria perolehan SKS minimal yang ditetapkan dalam pedoman kegaitan perkuliahan oleh Tim Penyusun Pedoman Akademik (2013) dalam pasal 22 ayat (2) dinyatakan bahwa mahasiswa boleh melanjutkan studi di fakultas masing-masing jika telah mengikuti 4 semester dengan perolehan sekurang-kurangnya 46 sks. Data rata-rata jumah SKS yang telah diprogram mahasiswa PMTK angkatan 2012 selama 4 semester adalah sebanyak 88,51 SKS. Hal ini menunjukkan bahwa mahasiswa telah mampu memenuhi standar minimal perolehan SKS, yang artinya mahasiswa dapat melanjutkan studinya di Prodi PMTK. 
Prestasi Akademik dan Non Akademik Mahasiswa Prodi Pendidikan Matematika Angkatan 2012 Fakultas Tarbiyah dan Keguruan IAIN Antasari Banjarmasin

2. Prestasi Non Akademik

Berdasarkan data skor SKK yang diperoleh, prestasi non akademik mahasiswa dapat diuraikan sebagai berikut:

Tabel 5. Kualifikasi Skor SKK Mahasiswa

\begin{tabular}{|c|c|c|c|}
\hline Predikat & IPK & F & $(\%)$ \\
\hline Istimewa & $86-$ ke atas & 22 & 20,56 \\
\hline Baik sekali & $76-<86$ & 22 & 20,56 \\
\hline Baik & $66-<76$ & 8 & 7,48 \\
\hline Cukup & $50-<66$ & 55 & 51,40 \\
\hline
\end{tabular}

Berdasarkan tabel 5, dari 111 mahasiswa yang didata perolehan skor SKK nya selama empat semester, diperoleh frekuensi dan persentase mahasiswa pada masing-masing kualifikasi. Sebanyak 22 mahasiswa atau $20,56 \%$ yang termasuk kualifikasi Istimewa. Sebanyak 22 mahasiswa atau $20,56 \%$ yang termasuk kualifikasi baik sekali. Pada kualifikasi baik terdapat 8 mahasiswa atau $7,48 \%$, sedangkan yang berada pada kualifikasi cukup yakni ada 55 mahasiswa atau 51,4\%. Adapun nilai rata-rata skor SKK mahasiswa adalah 69,38 kredit poin, dan nilai ini termasuk dalam kualifikasi baik.

Berdasarkan kriteria perolehan skor SKK minimal yang ditetapkan dalam pedoman kegaitan ekstra kurikuler oleh Tim Penyusun Pedoman Kegiatan Ekstra Kurikuler (2011) bahwa mahasiswa boleh mengikuti program PPL jika perolehan skor SKK sekurang-kurangnya 30 kredit poin. Data rata-rata skor SKK yang telah dikumpulkan mahasiswa PMTK angkatan 2012 selama 4 semester adalah sebanyak 69,38 kredit poin. Hal ini menunjukkan bahwa mahasiswa telah mampu memenuhi standar minimal perolehan skor SKK, yang artinya mahasiswa diperkenankan untuk mengikuti PPL. 


\section{Kesimpulan}

Berdasarkan hasil penelitian yang telah dilakukan, maka dapat disimpulkan bahwa: (1) Prestasi akademik mahasiswa Prodi PMTK berada pada kualifikasi amat baik ditinjau dari rata-rata IPK. Mahasiswa mampu memenuhi aspek perolehan SKS minimal selama empat semester yang artinya mahasiswa mahasiswa boleh melanjutkan studi di Prodi PMTK Fakultas Tarbiyah dan Keguruan IAIN Antasari. (2) Prestasi non akademik mahasiswa Prodi PMTK berada pada kualifikasi baik ditinjau dari rata-rata skor SKK. Mahasiswa telah memenuhi aspek perolehan skor minimal 30 SKK sebagai prasyarat untuk mengikuti Praktik Pengalaman Lapangan (PPL).

\section{Daftar Pustaka}

Nazir, M. 2003. Metode Penelitian. Ghalia Indonesia,Jakarta.

Sugiyono. 2007. Statistika Untuk Penelitian. CV Alfabeta, Bandung.

Tim Penyusun. 2011. Kegiatan Ekstra Kurikuler. Banjarmasin: Antasari Press.

Tim Penyusun. 2013. Pedoman Akademik IAIN Antasari Banjarmasin. Banjarmasin: Antasari Press.

Undang-undang RI Nomor 20 Tahun 2003 Tentang Sistem Pendidikan Nasional. Jakarta.

\section{Murdan}

IAIN Antasari

E-mail: murdan1966tar@gmail.com

\section{Rahmawati}

IAIN Antasari

E-mail: palimbangan_math@yahoo.com

\section{Ellen Davita Safaredha}

IAIN Antasari

E-mail: ellen_davita@yahoo.com 